This is an electronic reprint of the original article. This reprint may differ from the original in pagination and typographic detail.

Author(s): Tokila, Anu; Haapanen, Mika

Title: $\quad$ Evaluation of deadweight spending in regional enterprise financing

Year: $\quad 2012$

Version:

Please cite the original version:

Tokila, A., \& Haapanen, M. (2012). Evaluation of deadweight spending in regional enterprise financing. Regional Studies, 46(2), 185-201.

https://doi.org/10.1080/00343404.2010.497134

All material supplied via JYX is protected by copyright and other intellectual property rights, and duplication or sale of all or part of any of the repository collections is not permitted, except that material may be duplicated by you for your research use or educational purposes in electronic or print form. You must obtain permission for any other use. Electronic or print copies may not be offered, whether for sale or otherwise to anyone who is not an authorised user. 


\title{
Evaluation of deadweight spending in regional enterprise financing*
}

\author{
Anu Tokila and Mika Haapanen \\ Jyväskylä University School of Business and Economics
}

1 February 2010

\begin{abstract}
:
The problem of deadweight spending has been previously studied using diverse methods; however, regional variations in deadweight spending have not yet been considered. We conduct an evaluation of regional business subsidies in Finland during 2000-2003. Our analysis reveals regional differences in deadweight spending in proportional and, particularly, in monetary terms. Deadweight spending is dependent on many firm-, project-, and regional-level factors, which also largely account for regional differences. However, there seems to be some regional variation in deadweight spending that originates from differences in the subsidy processes among regions.
\end{abstract}

Keywords: enterprise financing, regional policy, deadweight spending, business projects, subsidies

JEL-codes: R58, H25, L53

\footnotetext{
* Published as: Tokila, A. \& Haapanen, M. (2012) "Evaluation of deadweight spending in regional enterprise financing", Regional Studies, 46(2), 185-201 Additional results are available at http://users.jyu.fi/ mphaapan/
} 


\section{Introduction}

Many governments, especially in OECD countries, grant business subsidies to promote growth and employment in regions that lag behind economically (Glancey and McQuaid, 2000; OECD, 2000). The European Union and all its member states also provide this type of subsidies (e.g. Mercado et al., 2001; MoLLE, 2007). Two main arguments, namely, equity and efficiency, motivate these subsidies. The equity argument states that the government should aim to equalise regional levels of development and thus should help firms with economic problems in economically backward regions. The firms in these regions do not benefit from agglomeration effects, which might lead to growing polarisation between regions without government intervention (BERGSTRÖM, 2000). The second argument regarding efficiency emphasises the role of the government in reducing different market failures that hinder firms from implementing profitable projects. Such market failures are found to be higher in more geographically remote regions (COVAL and MosKowITZ, 1999). However, government efforts to correct market failures may lead to government failure in such efforts due to inefficient interventions (see e.g. Winston, 2006).

A loss of efficiency may arise from at least two reasons. Public subsidies may encourage inefficient firms to take on non-profitable operations. Caballero et al. (2009) recently showed how this kind of subsidising leads to lower levels of job creation, higher levels of job destruction as well as lower productivity. Inefficiencies may also arise if firms could implement their projects even without public subsidies. In this paper, we are interested in deadweight spending, that is, funding allocated to this kind of non-additional projects. This topic has become increasingly important in EU expenditure evaluations in which context the demands to maximise the added value of spending have risen (MAIRATE, 2006). 
Deadweight spending has been studied using a variety of methods (e.g. Robinson et al., 1987; Foley, 1992; De Koning, 1993); some studies have even focused on spending in regionally allocated subsidies (LENIHAN, 1999; LENIHAN, 2004; TOKILA AND HAAPANEN, 2009). However, a regional comparison of deadweight spending has been absent in previous studies, even though most subsidy schemes are allocated on a regional basis. EU regional aid is also granted according to the level of disadvantage experienced by a region and it absorbs the largest share of the EU budget (e.g. Baldwin and Wyplosz, 2006). Many critics consider the European regional (i.e., cohesion) policy very inefficient, taking up only a lot of resources and employing an army of bureaucrats (Molle, 2007). Thus, given the size of the expenditures, it is relevant whether this amount of public money is wasted spending or not.

If a policy is well specified, deadweight spending should be minimal, and no regional differences should emerge. To analyse this question, we conduct an ex ante evaluation of the regional business subsidies in Finland during 2000-2003, which is the beginning of the recent EU programme period 2000-2006. More precisely, possible deadweight loss is measured from the ex-ante perspective. Using a five step scale, company analysts rank each applicant project before subsidizing according to their possible deadweight level. The paper (1) develops a method for financial measurement of regional deadweight spending, (2) aims at explaining determinants and differences of them, and (3) gives policy recommendations of alternative subsidy schemes. An ex ante evaluation is based on information available before the implementation of projects, and as such, it is needed to ensure the internal coherence of the programme (see JAKOBY, 2006). It can also be used to improve the planning of future EU regional policy programmes. As assessed ex ante, deadweight spending represents funding that is accepted as wasted in advance. That is, it is not necessarily the same as deadweight spending realised ex post (cf. TOKILA and HAAPANEN, 2009). 
Next, prior literature on deadweight spending is discussed. The Finnish subsidy system is briefly described, followed by a discussion of our unique data, which include 5744 private sector business projects that were granted public subsidies of nearly $€ 205$ million during 2000-2003. Deadweight spending is estimated for the National Assisted Areas of European regional policy. Our descriptive results show substantial regional differences in deadweight spending, which contradicts the hypothesis that the allocation of subsidies is coherently specified. To provide an explanation, an ordered probit model is estimated for each assisted area. A decomposition analysis is implemented to study the extent to which pair-wise regional differences in the deadweight spending can be explained by differences in business projects across the assisted areas. Before the concluding remarks, the policy implications for alternative policy schemes are discussed. These alternative scenarios are formed on the future predictions of business subsidy schemes according to which the subsidies will be diminished and concentrated only on the poorest regions; see COUNCIL OF THE EUROPEAN UNION (2006) and EUROPEAN COMMISSION (2004a, 2004b) for further details.

\section{Literature on deadweight spending}

Deadweight spending can be defined and estimated in different ways. Generally, deadweight spending $(\%)$ is measured as that share of a subsidy that is not required to implement a project. Deadweight spending can also be measured in terms of employment non-additionality, that is, in terms of jobs that would have been created without the subsidy; see e.g. Picard (2001) and Lenihan and Hart (2006). Both approaches are used to evaluate different kinds of subsidies, but in the end, they both describe the same phenomenon, namely, public finance that is not strictly required. In this study, deadweight spending is defined as wasted spending in monetary terms, whereas the degree of deadweight refers to its proportional share from the subsidy. 
Deadweight spending is calculated from the total amount of public subsidy granted to each project multiplying that by the degree of deadweight.

Theoretically, deadweight is defined as one of the two counterfactual components of additionality $^{1}$; the other is displacement ${ }^{2}$. Additionality measures the net sum of the direct and indirect impacts of intervention, whereas possible deadweight and displacement tend to reduce them. At the project level, deadweight can be identified as non-additionality (LUUKKONEN, 2000), which is the extent to which projects would have gone ahead even without public assistance; see also Robinson et al. (1987). The studies on deadweight represent "external reviews on financial efficiency" in the field of policy evaluation; see the classification in TUROK (1990). These studies emphasise efficiency in the provision of public finance instead of effectiveness in generating desired economic outcomes (FOLEY, 1992). The interest in deadweight developed substantially in the 1980s (e.g. LAYARD and NiCKELL, 1980; ZIMMERMANN, 1985; RoBINSON et al., 1987). Along with the increasing importance of EU regional policy, the concept of deadweight and other related topics have been brought back into academic debate (LeniHAn, 1999, 2004; LuUKKONEN, 2000; PiCARD, 2001; Heiss, 2003; LENIHAN and HART, 2004; LENIHAN et al 2005; TOKILA et al., 2008).

Since deadweight spending represents a loss of efficiency, the goal of the government should be to avoid or minimise deadweight spending. The evidence from prior studies shows that deadweight spending is a serious problem. While the actual results vary according to the projects examined and the assumptions made deadweight spending has been observed to be as large as $90 \%$ of subsidies (e.g. FOLEY, 1992), although DE KONING (1993) discovered deadweight spending as low as 40\%. LENIHAN (1999) and LENIHAN et al. (2005) found deadweight spending between $40 \%$ and $80 \%$. LENIHAN and HART (2004) estimated the range of deadweight spending to be $42.6 \%$ to $55.8 \%$, but their recent study (LENIHAN and HART, 2006) pegged this figure even higher at $73.2 \%$. 
TOKILA and HAAPANEN (2009) provided rather inexact previous figures from Finland. They estimated deadweight spending between $0.2 \%$ and $63.5 \%$ using a public assessment.

Even if policies are planned carefully, deadweight spending is not completely avoidable because the government never has full information about a firm's actions in the absence of the subsidy (LAYARD and NICKELL, 1980). The source of deadweight spending lies in the asymmetry of information between the government and the private firm (PICARD, 2001). This logic is supported by TOKILA and HAAPANEN (2009) with respect to Finnish data.

\section{Data and business subsidies}

The Ministry of Trade and Industry (KTM) is the major distributor of aid to business, with over $50 \%$ of all subsidy appropriations in Finland. Although KTM participates in business venturing through many instruments such as loans and guarantees, we are concerned with non-repayable grant subsidies. That is, the recipient firm is not obliged to pay back the grant to the distributor. ${ }^{3}$ In the programme period 2000-2006, three types of direct business subsidies were available for firms: subsidies for investments, business start-ups and development projects. These subsidies were granted to micro, small and medium-sized enterprises ${ }^{4}$ as well as larger enterprises in rare cases.

Investment subsidies can be granted to a firm for fixed asset investment projects when the firm is starting its business, expanding its operations, or modernising its fixed assets. A start-up subsidy can be granted to a small business starting its operations. Development subsidies can be granted for projects that enhance the competitiveness or internationalisation of an enterprise in the long term (MINISTRY OF JUSTICE, 2006). For development projects, the intensity of assistance is generally higher, reaching up to $50 \%$

of accepted costs. Start-ups are eligible to support up to $45 \%$ of accepted costs. With 
regard to investment projects, small firms may be granted $10 \%-30 \%$ of costs and medium-sized firms 5\%-20\% of costs, but these figures are only directive and depend on the National Assisted Areas (see details below; MinisTRY OF JUSTICE, 2000).

The subsidies are administered from the 15 local Employment and Economic Development Centres, where they are also mostly granted. ${ }^{5}$ To be subsidised, a business must present feasible project and financing plans along with an assessment made by the company analysts who deal with subsidy applications at the Employment and Economic Development Centres. In the assessment process, the project, the applicant firm and the need for public finance are fully described and evaluated. In addition, the predicted impacts of the project must be favourable.

We investigate deadweight spending in projects for which KTM granted subsidies between 2000 and 2003. ${ }^{6}$ Our data set is comprised of all financed projects, though only those conducted by private sector firms were selected for analysis. ${ }^{7}$ The total amount of subsidies granted to the 5744 projects under study was nearly $€ 205$ million. In terms of project costs their total value was $€ 906$ million with the average of $€ 158000$; see Table 2 for details. The data set is more extensive than that used by many previous studies on deadweight spending; see reviews by FOLEY (1992) and LENIHAN et al., (2005). It includes a broad range of advance information on firms and their projects (see Table 4 below). Importantly, the register data set also contains information on the assessment process through which the project and the firm are evaluated ex ante. This advance view on deadweight spending distinguishes this study from many previous, ex post studies that have used data collected after the project (e.g. Lenihan, 1999, 2004; see, however, Roper et al., 2004, for ex ante evaluations).

A fundamental difficulty in any type of evaluation is to establish what would have happened in the absence of intervention (MARTIN and TYLER, 2006; see also discussion 
in BASLÉ, 2006). In our study, the counterfactual is formed in an assessment in which company analysts answer a hypothetical question of what will happen if the project was not subsidised; in other words, this question evaluates the level of deadweight. The assessment is based on an extensive analysis of the firm and its market, industry and regional conditions. The possible deadweight options are as follows: (1) the project will be abandoned; (2) the project will be implemented on a reduced scale; (3) the project will be implemented on a reduced qualitative level; (4) the project will be implemented at a later date; and (5) the project will be implemented unchanged. Hence, option (1) implies zero deadweight; options (2)-(4) imply partial degrees of deadweight; and option (5) implies pure deadweight. This ex ante deadweight evaluation represents the public-sector assessment of the necessity of a subsidy. Thus, it is not necessarily equivalent to the firm's true need for a public subsidy, but rather it can be interpreted as accepted wasted money, since the projects are subsidised even on the condition that they yield deadweight spending.

The frequency distribution of this deadweight measure is shown in Table 1. Over $80 \%$ of projects would have been implemented to some degree even without a subsidy. Thus, some form of deadweight exists in most projects. $^{8}$

\section{$\langle$ TABLE 1>}

This assessment is used in the calculation of deadweight spending, which measures the amount of spending on non-additional shares of the project. In practice, deadweight spending, $d_{i}$, is computed by multiplying the amount of public subsidy for project $i, s_{i}$, by the degree of deadweight, $\delta_{i j}$ :

$$
d_{i}=s_{i} \delta_{i j}, \quad j=1,2,3,4,5
$$


where the degree of deadweight varies between $0 \%$ and $100 \%$. Clearly, $\delta_{1}=0$ when deadweight is zero, and $\delta_{5}=1$ in the case of pure deadweight.

The three levels of partial deadweight are more problematic to convert into exact degrees of deadweight. To assist this process, 221 firms were interviewed after the initiation of their respective projects. The firms that reported a reduction in project scale described that without the subsidy the size of a project would be less intensive in terms of physical investments or services. A reduction in the qualitative level, instead, indicates that without a subsidy, the firm would purchase less technologically advanced or second-hand machinery; they may also use less qualified consultation or training. A later date indicates that the implementation of a project is delayed generally 6 to 12 months, though it can be delayed up to 36 months.

These qualitative findings together with the assessment guides of KTM imply that degree of (partial) deadweight is lower when it involves a reduction in scale than when it involves a reduction in qualitative level and highest when the project is only projected to start at a later date (see also LENIHAN and HART, 2004). Without exact a priori knowledge, it is at first assumed that degree of deadweight increases in even intervals. That is, $\delta_{2}=0.25$ (reduced scale), $\delta_{3}=0.5$ (reduced qualitative level), and $\delta_{4}=0.75$ (later date). Since our estimates depend on this operationalisation, other scales are used to check that this assumption is not driving our results (see the Appendix).

For the regional analysis, the National Assisted Areas classification during the programme period 2000-2006 is used (Fig. 1). This classification is based on the regional level of development and development needs. Assisted Areas 1 and 2 have higher rates of unemployment and weaker economic growth rates than the national average. Their economies depend heavily on the public sector as well as on agriculture and forestry. These two areas are identical to the European Union's Objective 1 
Programme Area (i.e., Northern and Eastern Obj. 1). Assisted Area 3 closely resembles the EU's Objective Programme Area 2. Despite their confusing official name, 'outside Assisted Areas' are eligible for some, though the smallest amount of assistance.

\section{$<$ FIGURE 1>}

Table 2 displays key descriptive statistics by region; see also Table 4 below and Table A1 in the Appendix. According to Article 87 of the treaty establishing the European Community, public subsidies should be mainly targeted at lagging and peripheral regions (i.e., National Assisted Area 1). Hence, it is quite surprising to find that the intensity of assistance is on average almost as high in Assisted Area 1 as it is outside the Assisted Areas. Although more public subsidies are on average given to projects in Assisted Area 1 than outside the Assisted Areas, the project costs are also highest in Assisted Area 1. At the aggregate level, the largest shares of total assistance are allocated to Assisted Areas 1 and 3, even though the number of subsidised projects is highest outside the Assisted Areas.

\section{$<$ TABLE 2>}

Regional deadweight measures are presented in Table 3. They show that the regional average of project-level deadweight spending varies between $32.3 \%$ in Assisted Area 1 and $38.2 \%$ in Assisted Area 3. The regional differences in average deadweight spending in monetary terms are more substantial. Average deadweight spending $(€)$ is negatively associated with regional development and is highest in Assisted Area 1. This result turned out to be robust to our methodological choices; see discussion in the Appendix. Furthermore, the descriptive results in Table 2 and 3 together suggest that regional differences in deadweight spending $(€)$ are due to the relatively large amount of public subsidies given for projects in Assisted Area 1 rather than to a greater degree of 
deadweight $(\%)$. The largest amount of wasted subsidies ( $€ 19.5$ million) occurs in Assisted Area 3. Overall, € 64.1 million can be regarded as wasted spending.

\section{<TABLE 3>}

\section{Methodology}

The level of project deadweight is measured using an ordered, five-level scale ranging from 1 to 5. To model its determination, an ordered probit model is estimated for each region $r$ (Assisted Area 1, 2, 3, and outside Assisted Areas). In each of these four regions, it is assumed that $y_{i r}$, the observed deadweight level associated with project $i$, is determined according to a latent variable $y_{i r}^{*}$ :

$$
\begin{aligned}
& y_{i r}^{*}=\beta_{r}^{\prime} x_{i r}+\varepsilon_{i r}, \quad i=1,2, \ldots, N_{r}, \quad r=1,2,3,4 \\
& y_{i r}=j, \quad \text { if } \quad \kappa_{(j-1) r}<y_{i r}^{*} \leq \kappa_{j r}, \quad j=1,2,3,4,5 \\
& \varepsilon_{i r} \sim N(0,1), \quad \sum_{r} N_{r}=N
\end{aligned}
$$

where $x_{i r}$ is the vector of independent variables; $\beta_{r}$ is a vector of unknown coefficients for a region $r$; and $\kappa_{i}$ is an unknown threshold parameter with $\kappa_{0}=-\infty$ and $\kappa_{5}=\infty$. For each region, the disturbance term, $\varepsilon_{i r}$, is assumed to have a standard normal distribution. $N_{r}$ is the number of observations in region $r$, and $N$ is the total number of observations.

To explain the determination of the deadweight level in each region, we use variables describing the characteristics of the firm, its project and its region (Table 4); see Appendix, Table A1 for descriptive statistics. The theoretical hypotheses of these variables are drawn from the access to finance and risk literature.

The dummy variable for a new firm indicates whether a firm was founded within a year or has been operating for a longer time. The size of a firm is measured in terms of employees and annual turnover as well as using a self-employment dummy. ${ }^{9}$ A firm's 
access to finance is likely to increase with business experience and size (STOREY, 1994; WrEN, 1998). Young firms do not have much evidence to show their level of competence and trustworthiness. Banks and other lenders may be too risk-averse or simply too unfamiliar with the new business to lend the money needed during a firm's early non-profitable and risky years. Small firms may also face financial constraints. Thus, public finance is more crucial for new and small firms, and thus, wasted spending on these firms can be assumed to be relatively low.

\section{<TABLE 4>}

Alongside the characteristics of a firm, we must pay attention to the characteristics of the project, as it may have risk attributes distinct from the firm itself. Project costs and public subsidies are included as well as the intensity of assistance, the latter of which measures the amount of subsidies relative to project costs. A high intensity of assistance may indicate dependence on public finance and thus decrease deadweight. At the same time, a high intensity and a large amount of public assistance may increase the chances of generating finance from the private sector. Three dummy variables control for the project type. Start-up projects are assumed to have low deadweight due to the risks in starting a business.

Seven industry dummies capture the influence of factors common to all projects belonging to the same industry. Wood and transport industries are assumed to show low rates of deadweight, as these industries are capital-intensive and have traditionally been supported by the state; see JUNKA (1998) for further analysis. Regional characteristics include unemployment rates, and disposable income and R\&D expenditure per capita. A low level of disposable income and a high unemployment rate indicate a low regional level of purchasing power, which can have a negative effect on the financial capacity of firms, thus inducing a severe need for subsidies. High R\&D is often connected to low 
levels of deadweight in project level (e.g. HEIJs, 2003), since it is linked with a positive social externality from which economic benefits are not fully incorporated by the firm. In regional level the effect can also be opposite, since the firm may benefit from others' $R \& D$ investments in the region. Because the analysed projects are from four consecutive years (2000-2003), we are able to capture annual changes in deadweight spending with three separate year dummies. It is expected that deadweight is largest at the beginning of the program period in 2000; that is, grants are probably distributed more loosely when plenty of money still exists.

After estimating the model for the level of deadweight, we compute the expected value of deadweight spending, $E\left(d_{i r}\right)$, as follows:

$$
E\left(d_{i r}\right)=s_{i r} \sum_{j=1}^{5} \delta_{j} P\left(y_{i r}=j\right)
$$

where $s_{i r}$ is the amount of subsidy given to project $i$ in region $r$, and $\delta_{j}$ is the assumed degree of deadweight at that level; see equation (1). $P\left(y_{i r}=j\right)$ is the estimated probability of deadweight level $j$, which is computed using the ordered probit model; see Greene (2008, p. 832). To evaluate the impact of particular explanatory variables on expected deadweight spending, the average marginal effects are used; see the Appendix for formulas and discussion.

Our descriptive analysis showed substantial regional differences in average deadweight spending. These regional differences may simply result from discrepancies in the observed characteristics of the business projects and firms, or they may result from various characteristics having divergent effects on deadweight spending. To evaluate the amount explained by the observed differences in these characteristics, we adopt NEUMARK's (1988) decomposition analysis; see also OAXACA and RANSOM (1994) and BAUER and SINNING (2008) for more details on this approach. Namely, the difference in 
the expected deadweight spending between two regions, $A$ and $B$, is expressed as follows:

$$
\begin{aligned}
E\left(d_{i A} \mid x_{i A}\right)-E\left(d_{i B} \mid x_{i B}\right) & =\left[E_{\beta^{*}}\left(d_{i A} \mid x_{i A}\right)-E_{\beta^{*}}\left(d_{i B} \mid x_{i B}\right)\right] \\
& +\left[E_{\beta_{A}}\left(d_{i A} \mid x_{i A}\right)-E_{\beta^{*}}\left(d_{i A} \mid x_{i A}\right)\right] \\
& +\left[E_{\beta^{*}}\left(d_{i B} \mid x_{i B}\right)-E_{\beta_{B}}\left(d_{i B} \mid x_{i B}\right)\right]
\end{aligned}
$$

The first term in square brackets on the right-hand side estimates the impact of the differences in the observed characteristics assuming similar behaviour across regions, whereas the two latter terms estimate the behavioural differences assuming the same observed characteristics. A pooled model is used to derive the coefficient vector $\beta^{*}$ in the absence of regional differences in the determination of deadweight spending. It captures the general structure of deadweight spending in the two regions under comparison. In practice, for each pair-wise comparison of regions, three models are estimated: one for region $A$, one for region $B$, and a pooled model for regions $A$ and $B$. Expected deadweight spending values are then calculated for each observation in the two regions, and the terms in equation (4) are computed using regional averages of these predictions.

\section{Results}

Table 5 displays the estimation results of the ordered probit models for deadweight; see equation (2). The first four columns provide estimates for the assisted areas, followed by estimates for the entire country. The latter estimates, however, conceal significant differences in the estimated behavioural parameters across the four areas; an approximate Likelihood Ratio test clearly rejected the homogenous specification in column 5. ${ }^{10}$ Therefore, we conclude that the separate regional models reported in columns 1-4 are warranted. However, these results are not discussed in more detail, as they are only an intermediate step in the computation of expected deadweight spending and the average marginal effects. 


\section{$\langle$ TABLE 5>}

The average marginal effects show the direction and size of the effects on deadweight spending (see Table 6). To allow for comparison across the assisted areas, the average percentage change in expected deadweight spending is reported in square brackets below the marginal effect. The implications of our methodological choices on these results are discussed in the Appendix.

As expected, deadweight spending tends to be smaller in projects implemented by recently established firms, ceteris paribus. The marginal effect is largest in Assisted Area 1, which is the area with the lowest level of economic development; expected deadweight spending decreases on average by $€ 1158(-6.6 \%)$. Though, the effect is not statistically significant. Outside the Assisted Areas, deadweight spending is much smaller at $-34 \%$ for projects run by a self-employed person than for other projects. In Assisted Area 3, deadweight spending decreases with the number of employees but increases with a firm's turnover; when turnover increases by $€ 1$ million, the expected deadweight spending increases on average by $€ 147$. Although the impact is statistically significant, it is small at $1.3 \%$.

\section{<TABLE 6>}

The interpretation of the marginal effects of public subsidies is complicated by the fact that a marginal change in the subsidy will also change the intensity of assistance. Therefore, we have also computed average marginal effects that allow for an indirect effect on deadweight spending; see equation (A2) in the Appendix. Our calculations imply that a $€ 1000$ increase in the amount of public subsidies increases deadweight spending on average by $€ 365$ (15.8\%) in Assisted Area 1, € 245 (10.2\%) in Assisted Area 2, € 299 (12.7\%) in Assisted Area 3, and € 227 (9.7\%) outside the Assisted Areas.

All these effects are statistically significantly different from zero. ${ }^{11}$ Similar 
computations for project costs imply that a $€ 10000$ increase in project costs has a negative impact on deadweight spending in Assisted Area 1 (- $€$ 237) but a positive impact in all other areas ( $€ 242-€ 537)$. By itself, the intensity of assistance has a significant negative effect on deadweight spending in Assisted Area 3 and outside the Assisted Areas, ceteris paribus. The negative effect in Assisted Area 2 and the positive effect in Area 1 are not statistically significant.

Even after controlling for other factors, deadweight spending in Assisted Area 1 is estimated to be much higher for investment and start-up projects at $20.9 \%$ and $15.9 \%$, respectively, relative to development projects (Table 6). In Assisted Area 3, deadweight spending is particularly small for start-up projects, and outside the Assisted Areas, it is particularly small for investment projects. No large differences exist between project types in Assisted Area 2. Looking at industry effects, deadweight spending tends to be particularly high for real estate, renting and business activities, which is the reference category, while it is small in the wood industry. For example, the difference across these sectors in deadweight spending is on average almost 27\% in Assisted Area 1. In Assisted Area 2, industry differences are considerably smaller, but again, deadweight spending is smallest in the wood industry. In Assisted Area 3 and outside the Assisted Areas, the lowest levels of deadweight spending are estimated for the transportation industry.

Of the regional variables, the average marginal effect of disposable income is only significant outside the Assisted Areas; a $€ 1000$ increase in disposable income per capita raises expected deadweight spending on average by $€ 544(7.3 \%)$. It is somewhat surprisingly that the effect of regional unemployment is significantly negative only in Assisted Area 3 (positive in Assisted Area 2 and outside Assisted Areas). In that same area (3), the impact of regional $R \& D$ expenditure on expected deadweight spending is positive. ${ }^{12}$ As we expected, deadweight spending tends to be higher during the 
beginning of the programme period (year 2000), when the directions are not stable and more funding is available. This finding calls for a more careful selection of subsidised projects over the course of the programme period, particularly in Assisted Area 3.

Now we turn to the question of whether the significant regional differences in deadweight spending can be explained by differences in project, firm, and regional characteristics. Table 7 displays the decomposition of expected pair-wise regional differences in deadweight spending; see equation (4). The decomposition breaks differences down into explained and unexplained composites. In the first row, Assisted Areas 1 and 2 are compared. The results imply that of the average difference in expected deadweight spending ( $€ 2$ 080), approximately $46 \%$ is explained by the characteristics under analysis. For all other pair-wise comparisons, a considerably larger proportion is explained (93.3-99.8\%). For example, the largest difference in expected deadweight spending ( $€ 9$ 347) is almost entirely (99.7\%) explained by the differences in the observed factors between projects in Assisted Area 1 and outside the Assisted Areas. Robustness checks are reported in the Appendix.

\section{$<$ TABLE 7>}

\section{Policy implications}

The tendency in EU regional policy is to limit available funding and to concentrate on the least developed regions (see e.g. MAIRATE, 2006). Thus, we compare current policy to schemes in which subsidies are reallocated across regions and also diminished in terms of aggregate size (Table 8). In the alternative schemes, grants are redistributed evenly relative to the current level of subsidies given to projects. Then, deadweight spending is predicted for each project, and regional aggregates are computed.

The schemes that reallocate subsidies from developed regions to less developed regions lower deadweight spending. When subsidies are evenly distributed from outside 
Assisted Areas to projects in all assisted areas (i.e., case $2 \mathrm{a}$ in Table 8), total deadweight spending is decreased by $18 \%$. A larger decrease is achieved if subsidies are concentrated into the most remote regions, i.e., in Assisted Areas 1 and 2. When these subsidies are merely distributed to Assisted Area 1, the decrease is $20.5 \%$ (case 2c), and it is even higher (22.6\%) when divided between Areas 1 and 2 (case $2 b$ ). Reducing the amount of subsidies by $50 \%$ diminishes deadweight spending by $69.6 \%$ if subsidies are distributed to Assisted Area 1 (case 3b) and by approximately $54.7 \%$ if they are distributed to Assisted Areas 1 and 2 (case 3a). The higher decrease in the case $3 \mathrm{~b}$ results from greater elasticity of deadweight spending with respect to amount of subsidies in Assisted Area 1 than 2.

\section{$\langle$ TABLE 8>}

\section{Discussion}

In this paper, we have estimated the level of deadweight spending across regions in Finland and have provided explanations for regional differences. Based on previous literature, a relatively high deadweight was expected, though the literature provided little insight regarding regional variation. Thus, our results provide new information on the regional allocation of enterprise financing.

First, our descriptive analysis of deadweight spending showed substantial regional differences. In monetary terms deadweight spending is on average the highest in Assisted Area 1 and the lowest outside the Assisted Areas. This difference is not explained by the variation in the degree of deadweight $(\%)$ but rather by the sizes of subsidies and projects $(€)$. Thus, allocating more resources to developed areas would not decrease wasted spending.

Second, our econometric analysis showed regional variation in the determination of deadweight spending. These differences were particularly large for variables describing 
the type of the project and the size and industry of the firm. Thus, the efficiency of regional business subsidies could be increased by favouring different kinds of projects in different regions rather than applying nationally mandated guidelines.

Third, the observed discrepancies explained a majority of the pair-wise regional differences in expected deadweight spending. Only the comparison between Assisted Areas 1 and 2 indicates a substantial level of unexplained difference in spending. Hence, subsidies may be wasted more easily in Assisted Area 1 than in Assisted Area 2. These differences should be studied more carefully in order to improve allocation systems.

Finally, we also compared the EU current policy to alternative schemes that reallocate subsidies from developed regions to less developed regions. If resources allocated to business subsidies are to be decreased, the highest efficiency in terms of avoiding deadweight can be achieved by concentrating subsidies to these least developed areas. The negative relationship between deadweight and economic development is understandable, since distant locations often provide weaker opportunities for private finance (cf. FELSENSTEIN and FLEISCHER, 2002).

This is the first paper addressing regional differences in deadweight spending, and thus, it has developed new methods for determining overall deadweight spending. One limitation to our approach is that the results cannot be generalised to all business projects in Finland due the selectivity of the subsidised projects. Our approach can be seen as complementary to the recent econometric treatment literature that has been used to estimate the impact of treatment (subsidy) on the treated (subsidised projects) as well as the net impact of subsidies (the average treatment effect). The implementation of micro-econometric treatment models would have required information on a control group, that is, on projects that were not subsidised. ${ }^{13}$ Although our data included 
detailed information on subsidised projects, data on a suitable control group were missing. However, in an analysis of deadweight, the control group approach is problematic in many senses, since non-assisted firms do not form a reliable control group with similar characteristics (STOREY, 1990). One obvious difference emerges from the fact that they either did not apply or did not obtain regional assistance, and thus, they probably had no desire to expand their activities (ARMSTRONG and TAYLOR, 2000). Second, although our results seem robust to the implemented deadweight measure and computational assumptions regarding partial deadweight, a clear limitation of our approach is that a degree of deadweight between $0 \%$ and $100 \%$ must be assumed for the partial deadweight case.

\section{Conclusion}

This paper has provided insight regarding efficiency of regional enterprise financing. It shows that regional business subsidies are not intended to be very efficient, since relatively high wasted spending is accepted ex ante. Higher levels of efficiency could be achieved by concentrating on projects that cannot be implemented in the absence of a subsidy, that is, on projects with zero deadweight. However, even if policies are planned carefully, deadweight spending is not completely avoidable, since the government never has full information about a firm's action in the absence of a subsidy. Thus, better knowledge about deadweight and the attainment of higher efficiency requires a better exchange of information from firms, and private financiers to the public sector. This can be done, for example, by developing more efficient screening and information systems; see the discussion in LUNDSTRÖM and STEVENSON (2009) and TAKALO and TANAYAMA (2009). Trust and knowledge between the public sector and the firms can also be improved with long-term relations. Defining an 'acceptable level' of deadweight would also require thorough cost-benefit analysis of subsidies, but anything below the 
previously documented average of 50\% (ARMSTRONG and TAYLOR, 2000) could be interpreted as a positive sign.

Deadweight spending is not unambiguously a negative thing, at least not if the projects yield positive externalities, such as regional spillover and leverage effects (e.g. HART and LENIHAN, 2006). Even in the presence of deadweight spending, subsidies may have a variety of direct and indirect positive impacts on regional development. However, subsidies may also slow down necessary restructuring and creative destruction (see, for example, CABALLERo et al., 2009). To achieve a fuller picture of the added value of regional subsidies across different types of areas, a further evaluation of their effectiveness and displacement effects is certainly needed. Thus, it is necessary to consider the trade-off between deadweight spending and the net effects of subsidised projects.

\section{Appendix}

\section{$\langle$ TABLE A1>}

\section{Computation of average marginal effects}

To evaluate the impact of particular explanatory variables on the expected deadweight spending, average marginal effects are computed. By differentiating equation (3), the marginal effect of $k^{\text {th }}$ explanatory variable $x_{i r}^{k}$ for a project $i$ is:

$$
\frac{\partial E\left(d_{i r} \mid x_{i r}\right)}{\partial x_{i r}^{k}}=s_{i r} \sum_{j=1}^{5} \delta_{j} \frac{\partial P\left(y_{i r}=j\right)}{\partial x_{i r}^{k}} \quad \text { if } \quad x_{i r}^{k} \neq s_{i r},
$$

where the partial derivatives $\partial P_{j} / \partial x_{i r}^{k}$ can be computed as in GREENE (2008, p. 833). However, equation (A1) is no longer valid for computing the marginal effect of subsidy $s_{i r}$. In that case, it must be computed as a sum of the direct and indirect effects on deadweight spending using the product rule of differentiation: 


$$
\frac{\partial E\left(d_{i r} \mid x_{i r}\right)}{\partial s_{i r}}=\sum_{j=1}^{5} \delta_{j} P\left(y_{i r}=j\right)+s_{i r} \sum_{j=1}^{5} \delta_{j} \frac{\partial P\left(y_{i r}=j\right)}{\partial s_{i r}},
$$

where the computation of $\partial P_{j} / \partial s_{i r}$ is complicated by the fact that a marginal change in the subsidy will also change the intensity of assistance, which is another explanatory variable. These project-level marginal effects are computed as discrete changes for noncontinuous variables (see GREENE, 2008, p. 775). Finally, average marginal effects are computed as averages over all projects, as recommended by CAMERON and TRIVEDI (2005, p. 467).

\section{Robustness checks}

First, the sensitivity of our descriptive findings is assessed by computing the regional average of deadweight spending in Table 3 using alternative deadweight measures and computational assumptions on partial deadweight. Alternative deadweight measures use self-reports from 221 projects: that is, direct self-assessment of deadweight and an indirect measure of deadweight based on grant replacement possibilities. Alternative computational assumptions on the partial deadweight assume either that reduced scale, reduced qualitative level and later date all imply $50 \%$ of deadweight; or that reduced scale implies 50\%, reduced qualitative level implies $70 \%$ and later date implies $90 \%$ of deadweight (so called 'a conservative view'). These numbers are used in place of $25 \%$, $50 \%$, and $75 \%$ in equation (1). The findings remain qualitatively unchanged. Regardless of our methodological choices, the average deadweight spending (€) was negatively associated with regional development.

Second, the average marginal effects reported in Table 6 were also computed using alternative computational assumptions on the partial deadweight. Again, only the quantity of marginal effects changed; their signs remained the same. Note that as long as the order of partial deadweight options remains unchanged (i.e., the degree of 
deadweight is highest when the project will be implemented at a later date and smallest when it is implemented at a reduced scale), then the estimates of the ordered probit models reported in Table 5, including the probabilities $P\left(y_{i r}=j\right)$ as well as the signs of the marginal effects in Table 6, do not depend on the assumed magnitude of $\delta_{j}$. Full results from the first two robustness checks are available from the authors upon request.

Third, the decomposition analysis (c.f. Table 7) was conducted using alternative computational assumptions. The results are reported in Table A2. For brevity, only the pair-wise regional differences due to differences in characteristics are reported. As seen in columns A.1-A.3, the results are quite robust to the computation of deadweight spending. Finally, we investigated the role of missing values that have been imputed for turnover and number of employees in our analyses. Note that 812 projects with missing values were deleted. Decomposition analysis was also performed using the alternative computational assumptions; see results in columns B.1-B.3. Again our conclusions remain unchanged; apart from the difference between Areas 1 and 2, a very large proportion of the regional differences in deadweight spending can be explained by the observed factors.

$\langle$ TABLE A2>

\section{References}

Angrist J. D. and Pischke J.-S. (2009) Mostly Harmless Econometrics: An Empiricist's Companion. Princeton University Press, Oxford.

Armstrong H. and Taylor J. (2000) Regional Economics and Policy (3rd ed.). Blackwell, Oxford

Baldwin R. and Wyplosz C. (2006) The Economics of European Integration (2nd ed.). McGraw-Hill, London. 
BASLÉ M. (2006) Strengths and weaknesses of European Union policy evaluation methods: ex-post evaluation of Objective 2: 1994-99, Regional Studies 40, 225236.

BAuER T. K. and Sinning M. (2008) An extension of the Blinder-Oaxaca decomposition to nonlinear models, Advances in Statistical Analysis 92, 197-206.

Bergström F. (2000) Capital subsidies and the performance of firms, Small Business Economics 14, 183-193.

Caballero R. J., Hoshi T. and Kashayap A. K. (2009) Zombie lending and depressed restructuring in Japan, American Economic Review 98, 1943-1977.

CAMERON A. C. and Trivedi P. K. (2005) Microeconometrics: Methods and Applications. Cambridge University Press, Cambridge.

Council of The European Union (2006) Council Decision of 6 October 2006 on Community strategic guidelines on cohesion (2006/702/EC), Official Journal of the European Union, L 291/11.

Coval J. D. and Moskowitz T. J. (1999) Home bias at home: local equity preference in domestic portfolios, The Journal of Finance 54, 2045-2073.

DAVEnport S., GRimes C. and DAVIES J. (1998) Research collaboration and behavioural additionality: a New Zealand case study, Technology Analysis \& Strategic Management 10, 55-67.

DE Koning J. (1993) Measuring the placement effects of two wage-subsidy schemes for the long-term unemployed, Empirical Economics 18, 447-468.

European Commission (2003) The Annex of Recommendation 2003/361/EC, Official Journal of the European Communities 66 41, 3 November. European Commission, Brussels.

European Commission (2004a) Communication from the Commission to the Council and the European Parliament: Financial perspectives 2007-2013, COM (2004) 487. 
European Commission (2004b) Communication from the Commission to the Council and the European Parliament: Building our common Future Policy challenges and Budgetary means of the Enlarged Union 2007-2013, COM (2004) 101.

FELSENSTEIN D. \& FleisCHER A. (2002) Small-scale entrepreneurship and access to capital in peripheral locations: an empirical analysis, Growth and Change 33, 196215.

FOLEY P. (1992) Local economic policy and job creation: a review of evaluation studies, Urban Studies 29, 557-598.

Georghiou L., Rigby J. and CAmeron H. (Eds) (2002) Assessing the socio-economic impacts of the framework programme. PREST Publications.

Glancey K. S. and McQuaid R. W. (2000) Entrepreneurial Economics. Palgrave, New York.

GreENE W. H. (2008) Econometric Analysis (6th ed.). Prentice-Hall, New Jersey.

HART M. and LENIHAN H. (2006) Evaluating additionality and leverage: the interplay between public and private sector equity finance in Ireland (2000-2002), Venture Capital 8, 331-351.

HEIJS J. (2003) Freerider behaviour and the public finance of R\&D activities in enterprises: the case of the Spanish low interest credits for R\&D, Research Policy 32, 445-461.

JAKOBY H. (2006) Evaluation as part of the regional policy life cycle: The example of Nort Rhine-Westphalia, Germany, Regional Studies 40, 281-284.

JunKA T. (1998) Trends in the public support to industries in 1984-1996 (in Finnish). Government Institute for Economic Research, Discussion Paper No. 165.

KANGASHARJU A. (2007) Do wage subsidies increase employment in subsidized firms?, Economica 74, 51-67.

LAYARD D. and NiCKELl S. J. (1980) The case for subsidizing extra jobs, Economic Journal 90, 51-73. 
LENIHAN H. (1999) An evaluation of a regional development agency's grants in terms of deadweight and displacement, Environment and Planning C: Government and Policy 17, 303-318.

LENIHAN H. (2004) Evaluating Irish industrial policy in terms of deadweight and displacement: a quantitative methodological approach, Applied Economics 36, 229_ 252.

LENIHAN H. and HART M. (2004) The use of counterfactual scenarios as a means to assess policy deadweight: an Irish case study, Environment and Planning $C$ : Government and Policy 22, 817-839.

LENIHAN H. and HART M. (2006) Evaluating the additionality of public sector assistance to Irish firms: a question of ownership? Policy Studies 27, 115-133.

LENIHAN H., HART M. and RoPER S. (2005) Developing an evaluative framework for industrial policy in Ireland: fulfilling the audit trail or an aid to policy development, in Economic and Social Research Institute, Quarterly Economic Commentary Summer 2005, pp. 69-85.

Lundström A. and SteVenson L. A. (2005) Entrepreneurship Policy: Theory and Practice. International Studies in Entrepreneurship (Vol. 9), Springer-Verlag, New York.

LUUKKONEN T. (2000) Additionality of EU framework programs, Research Policy 29, $711-724$.

MaIRATE A. (2006) The 'Added Value' of European Union Cohesion Policy, Regional Studies 40, 167-178.

MARTIN R. and TYLER P. (2006) Evaluating the impact of the structural funds on Objective 1 regions: an exploratory discussion, Regional Studies 40, 201-210.

Mercado S., Welford R. and Prescott K. (2001) European Business (4th ed.). Financial Times, Prentice Hall. 
MiniSTRY OF JUSTICE (2000) Decree of Council of State, 1200/2000, in The Statutes of Finland No. 1199-1201 Ed J Linhala (Edita, Helsinki), pp. 3202-3209.

MinistRY OF JUSTICE (2006) Aid to Business Act 1068/2000 Finnish Law I (Talentum, Finland) translation available http://www.finlex.fi/en/laki/kaannokset/2000/en20001068.pdf.

Mole K., Hart M., Roper S. and SAal D. (2008) Differential gains from Business Link support and advice: a treatment effects approach, Environment and Planning C: Government and Policy 26, 315-334.

Molle W. (2007) European Cohesion Policy. Routledge, Oxon.

NEUMARK D. (1988) Employers' discriminatory behaviour and the estimation of wage discrimination, Journal of Human Resources 23, 279-295.

OAXACA R. L. and RANSOM M. (1994) On discrimination and the decomposition of wage differentials, Journal of Econometrics 61, 5-21.

OECD (2000) OECD Small and Medium Enterprise Outlook 2000 Edition. OECD Publishing, Paris.

OECD (2009) OECD Factbook 2009: Economic, Environmental and Social Statistics, OECD Publishing.

PICARD P. M. (2001) Job additionality and deadweight spending in perfectly competitive industries: the case for optimal employment subsidies, Journal of Public Economics 79, 521-541.

Robinson F., Wren C. and Goddard J. (1987) Economic Development Policies: An Evaluative Study of Newcastle Metropolitan Region. Clarendon Press, Oxford.

Roper S., HewitT-Dundas N. and Love J. H. (2004) An ex ante evaluation framework for the regional benefits of publicly supported R\&D projects. Research Policy 33, 487-509.

STATISTICS FinLAND (2004) Business enterprises - net results and balance sheets 2002 (in Finnish), Statistics Finland, Helsinki. 
STOREY D. J. (1990) Evaluation of policies and measures to create local employment, Urban Studies 27, 669-684.

StOREY D. J. (1994) Understanding the Small Business Sector. Routledge, London.

TAKAlO T. and TANAYAMA T. (2009) Adverse selection and financing of innovations: Is there need for R\&D subsidies?, Journal of Technology Transfer, forthcoming.

TERvo H. (1989) A micro-level approach to the analysis of the displacement effects of regional incentive policy: the case of Finland, Regional Studies 23, 511-521.

TERvo H. (1990) Factors underlying displacement: an analysis of Finnish regional incentive policy using survey data on assisted firms, Applied Economics 22, 617628.

TOKILA A. and HAAPANEN M. (2009) Evaluating project deadweight measures: evidence from Finnish business subsidies, Environment and Planning $C$ : Government and Policy 27, 124-140.

TOKILA A., HAAPANEN M. and RITSILÄ J. (2008) Evaluation of investment subsidies When is deadweight zero?, International Review of Applied Economics 22, 585600.

TUROK I. (1990) Evaluation and accountability in spatial economic policy: a review of alternative approaches, Scottish Geographical Magazine 106, 3-11.

Winston C. 2006. Government failure vs. market failure: microeconomics policy research and government performance. AEI - Brookings Joint Center, Washington.

Wren C. (1998) Subsidies for job creation: is small best?, Small Business Economics 10, 273-281.

WREN C. (2007) Reconciling practice with theory in the micro-evaluation of regional policy, International Review of Applied Economics 21, 321-337.

ZimmermanN H. (1985) Der Mitnahmeeffekt. Inhalt und Meßkonzepte, dargestellt am Beispiel der Zuweisungen and Gemeinden, in Räumliche Aspekte des Kommunalen 
Finanzausgleichs, Forschungs- und Sitzungsberichte der Akademie für Raumforschung und Landesplanung, Vol. 159, Hannover, pp. 293-311. 


\section{FIGURES AND TABLES}

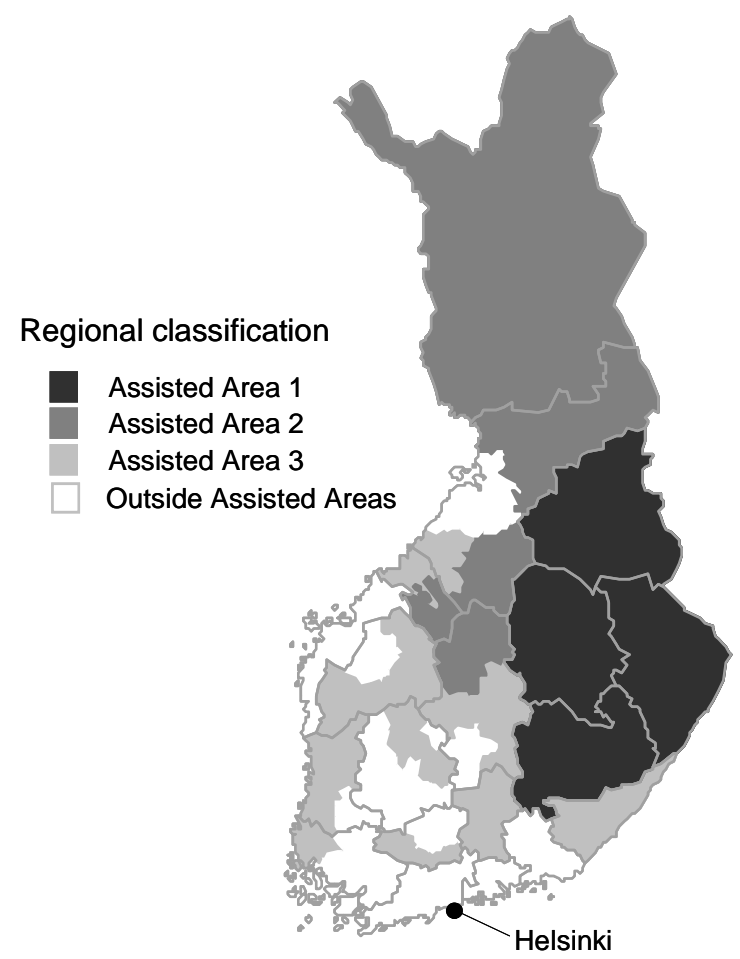

Fig. 1. National Assisted Areas in 2000-2006 in Finland (with the borders of NUTS3 regions)

Table 1. Frequency distribution of deadweight

\begin{tabular}{lcc}
\hline Deadweight & Number & Percentage \\
\hline (1) Zero deadweight & 967 & $16.8 \%$ \\
(2) Reduced scale & 2264 & $39.4 \%$ \\
(3) Reduced qualitative level & 1640 & $28.6 \%$ \\
(4) Later date & 791 & $13.8 \%$ \\
(5) Full deadweight & 82 & $1.4 \%$ \\
\hline Total & 5744 & $100 \%$ \\
\hline Notes: The number of observations is given first, followed by the percentages.
\end{tabular}


Table 2. Description of project characteristics by region

\begin{tabular}{lccccc}
\hline & $\begin{array}{c}\text { Assisted } \\
\text { Area 1 }\end{array}$ & $\begin{array}{c}\text { Assisted } \\
\text { Area 2 }\end{array}$ & $\begin{array}{c}\text { Assisted } \\
\text { Area 3 }\end{array}$ & $\begin{array}{c}\text { Outside } \\
\text { Assisted } \\
\text { Areas }\end{array}$ & $\begin{array}{c}\text { All } \\
\text { Areas }\end{array}$ \\
\hline $\begin{array}{l}\text { Project level averages } \\
\text { Public subsidies, } € 1000\end{array}$ & 63.2 & 47.5 & 31.1 & 21.2 & 35.6 \\
& $(197.7)$ & $(120.1)$ & $(70.0)$ & $(25.7)$ & $(106.0)$ \\
Project costs, $€ 1000$ & 209.6 & 177.4 & 193.8 & 91.8 & 157.8 \\
& $(685.8)$ & $(506.5)$ & $(1231.0)$ & $(194.5)$ & $(790.2)$ \\
Intensity of assistance, \% & 36.0 & 32.2 & 27.1 & 34.9 & 32.3 \\
& $(8.5)$ & $(9.9)$ & $(15.2)$ & $(16.3)$ & $(14.5)$ \\
Aggregate level & & & & & \\
Public subsidies, $€ 1000$ & 67959 & 35554 & 57412 & 44002 & 204917 \\
Project costs, $€ 1000$ & 225303 & 132668 & 357836 & 190403 & 906210 \\
Intensity of assistance, \% & 30.2 & 26.8 & 16.0 & 23.1 & 22.6 \\
\hline Number of observations & 1075 & 748 & 1846 & 2075 & 5744 \\
\hline Notes: Standard deviations are given in parentheses below the means. & &
\end{tabular}

Table 3. Deadweight and deadweight spending by region

\begin{tabular}{|c|c|c|c|c|c|}
\hline & $\begin{array}{l}\text { Assisted } \\
\text { Area } 1\end{array}$ & $\begin{array}{l}\text { Assisted } \\
\text { Area } 2\end{array}$ & $\begin{array}{l}\text { Assisted } \\
\text { Area } 3\end{array}$ & $\begin{array}{c}\text { Outside } \\
\text { Assisted } \\
\text { Areas }\end{array}$ & $\begin{array}{c}\text { All } \\
\text { Areas }\end{array}$ \\
\hline \multicolumn{6}{|l|}{ Distribution of deadweight } \\
\hline Zero deadweight, \% & 24.6 & 18.3 & 14.2 & 14.6 & 16.8 \\
\hline Reduced scale, $\%$ & 38.1 & 34.1 & 36.9 & 44.2 & 39.4 \\
\hline Reduced qualitative level, \% & 23.3 & 30.9 & 31.3 & 28.0 & 28.6 \\
\hline Later date, $\%$ & 11.5 & 16.3 & 17.0 & 11.2 & 13.8 \\
\hline Full deadweight, $\%$ & 2.5 & 0.4 & 0.5 & 2.0 & 1.4 \\
\hline Total, \% & 100.0 & 100.0 & 100.0 & 100.0 & 100.0 \\
\hline $\begin{array}{l}\text { Average project-level } \\
\text { deadweight snending } \%\end{array}$ & $\begin{array}{l}32.3 \\
(260)\end{array}$ & $\begin{array}{l}36.6 \\
(24.6)\end{array}$ & $\begin{array}{c}38.2 \\
(238)\end{array}$ & $\begin{array}{l}35.5 \\
(23.5)\end{array}$ & $\begin{array}{l}35.9 \\
(24.3)\end{array}$ \\
\hline Average project-level & 16.9 & 14.7 & 10.5 & 7.4 & 11.1 \\
\hline deadweight spending, $€ 1000$ & $(57.1)$ & $(34.4)$ & $(22.5)$ & $(11.5)$ & $(31.4)$ \\
\hline $\begin{array}{l}\text { Total deadweight spending, } \\
€ 1000\end{array}$ & 18161.6 & 10977.2 & 19466.4 & 15456.6 & 64061.7 \\
\hline Number of observations & 1075 & 748 & 1846 & 2075 & 5744 \\
\hline
\end{tabular}


Table 4. Definitions of variables

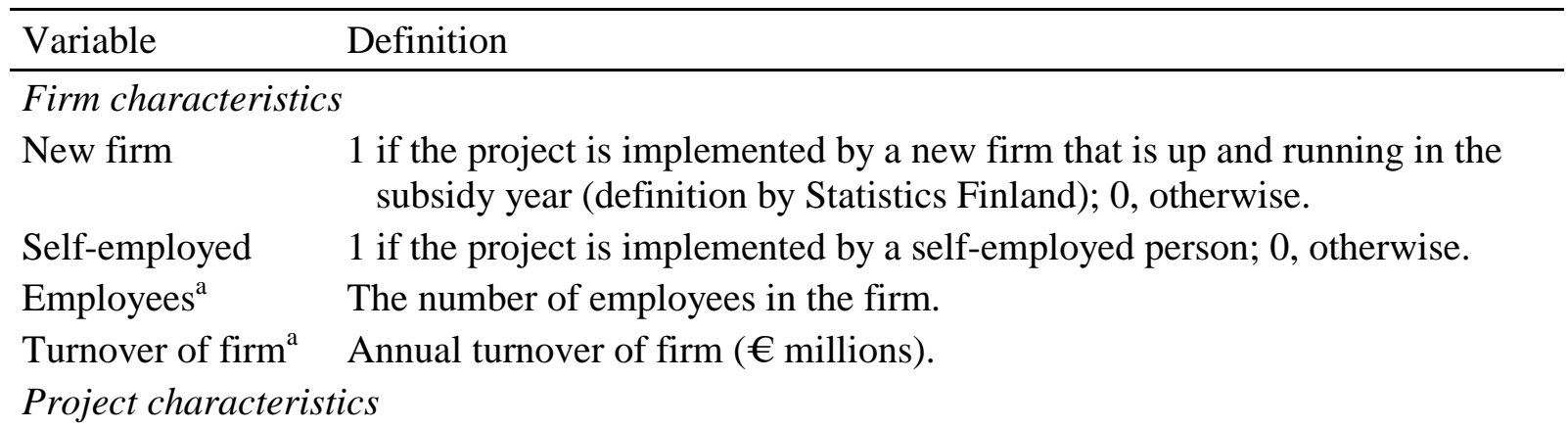

Project costs Total project costs (i.e., the purchasing cost of the fixed assets) as estimated by the firm in its subsidy application (€ 10000$)$.

Public subsidy Amount of public subsidy to the business project $(€ 10000)$.

Intensity of Ratio of the public subsidy to the project costs (\%).

assistance

Investment project 1 if the project is an investment project; 0, otherwise.

Start-up project $\quad 1$ if it is about starting up a business; 0 , otherwise.

Development $\quad 1$ if it is a development project (enhancing competitiveness or project internationalisation of enterprise); 0 otherwise. (reference)

Industry

Metal

1 if the project is manufacturing of fabricated metal products; 0 otherwise.

Wood

1 if the project is manuf. of wood and of products of wood and cork, incl. furniture, or of articles of straw and plaiting materials; 0 otherwise.

Other $\quad 1$ if the project is in another manufacturing industry (including textiles, manufacturing rubber and plastic products, food products and beverages); 0 otherwise.

Trade 1 if the project is in wholesale and retail trade, repair of motor vehicles, motorcycles and personal and household goods, or hotels and restaurants; 0 otherwise.

Transport $\quad 1$ if the project is in transport, storage and communication, or financial intermediation; 0 otherwise.

Business services 1 if the project is in real estate, renting, and business activities; 0 otherwise. (reference)

Other industries $\quad 1$ if the project is in another industry; 0 otherwise.

Regional characteristics

Unemployment Unemployment rate (\%) in the NUTS4 region where the firm is located. rate Source: Ministry of Employment and the Economy.

Disposable income Disposable income $(€ 1000)$ per capita in the NUTS4 region where the firm is located. Source: Statistics Finland.

R\&D expenditure Research and development expenditure ( $€ 1000)$ per capita in the NUTS4 region where the firm is located. Source: Statistics Finland.

Location $^{b}$

Assisted Area $1 \quad 1$ if the project is implemented in the National Assisted Area 1; 0, otherwise.

Assisted Area 21 if the project is implemented in the National Assisted Area 2; 0, otherwise.

Assisted Area $3 \quad 1$ if the project is implemented in the National Assisted Area 3; 0, otherwise.

Outside Assistance 1 if the project is implemented outside National Assisted Areas 1-3; 0, Areas otherwise.

Notes: Only projects of private firms are included. Data also include four year dummies (2000-2003) that describe when funding was granted. Industry dummies have been created using the TOL 2002 industrial classification. ${ }^{\text {a) }}$ Observations with missing information have been imputed. ${ }^{\text {b) }}$ See Ministry of Justice (2000) for a description of the Assisted Areas; see also Figure 1. 
Table 5. Parameter estimates of the ordered probit models

\begin{tabular}{|c|c|c|c|c|c|}
\hline Variable & $\begin{array}{l}\text { Assisted } \\
\text { Area } 1\end{array}$ & $\begin{array}{l}\text { Assisted } \\
\text { Area } 2\end{array}$ & $\begin{array}{l}\text { Assisted } \\
\text { Area } 3\end{array}$ & $\begin{array}{c}\text { Outside } \\
\text { Assisted } \\
\text { Areas }\end{array}$ & $\begin{array}{c}\text { All } \\
\text { Areas }\end{array}$ \\
\hline New firm & -0.090 & -0.030 & -0.078 & 0.000 & -0.030 \\
\hline Self-employed & -0.092 & 0.228 & -0.143 & $-0.600 * * *$ & $-0.205 * * *$ \\
\hline Employees & 0.000 & -0.002 & $-0.003 *$ & 0.002 & 0.000 \\
\hline Turnover of firm & 0.015 & 0.019 & $0.023 * *$ & -0.004 & $0.011 *$ \\
\hline Public subsidy & $-0.054 * *$ & $-0.055^{*}$ & $-0.018 * *$ & 0.013 & -0.006 \\
\hline Project costs & $0.013 * *$ & 0.010 & 0.000 & -0.003 & -0.001 \\
\hline Intensity of assistance & 0.013 & -0.009 & $-0.012 *$ & $-0.018 * * *$ & $-0.016 * * *$ \\
\hline Investment project ${ }^{\mathrm{a}}$ & 0.246 & -0.063 & 0.001 & -0.247 & $-0.179 * *$ \\
\hline Start-up project ${ }^{\mathrm{a}}$ & 0.188 & 0.102 & $-0.265^{* *}$ & 0.097 & -0.009 \\
\hline Metal $^{\text {b }}$ & $-0.191 *$ & 0.034 & -0.109 & -0.055 & $-0.100 * *$ \\
\hline Wood $^{\mathrm{b}}$ & $-0.412 * * *$ & -0.178 & -0.144 & -0.061 & $-0.182 * * *$ \\
\hline Other manufacturing ${ }^{\mathrm{b}}$ & $-0.211 * *$ & 0.010 & $-0.158 *$ & 0.010 & $-0.098 * *$ \\
\hline Trade $^{b}$ & -0.142 & 0.078 & -0.105 & -0.100 & -0.047 \\
\hline Transport $^{\mathrm{b}}$ & -0.208 & 0.031 & -0.381 & -0.174 & -0.122 \\
\hline Other industries ${ }^{b}$ & $-0.282 *$ & -0.106 & 0.036 & 0.069 & -0.022 \\
\hline Unemployment rate & -0.011 & $0.026 * *$ & $-0.039 * *$ & $0.037 * * *$ & $0.014^{* *}$ \\
\hline Disposable income & -0.162 & -0.056 & -0.009 & $0.119 * * *$ & $0.040 * *$ \\
\hline R\&D expenditure & -0.017 & -0.076 & $0.221 * *$ & -0.046 & 0.002 \\
\hline $2000^{c}$ & 0.076 & 0.086 & $0.234^{*}$ & 0.073 & $0.176 * * *$ \\
\hline $2001^{\mathrm{c}}$ & -0.198 & -0.053 & 0.031 & $0.178 * *$ & 0.054 \\
\hline $2002^{c}$ & -0.167 & -0.133 & 0.057 & 0.125 & 0.026 \\
\hline \multicolumn{6}{|l|}{ Threshold parameters } \\
\hline$\kappa_{1}$ & -2.460 & -1.551 & $-2.149 * * *$ & 0.308 & $-0.934 * * *$ \\
\hline$\kappa_{2}$ & -1.425 & -0.560 & -1.012 & $1.617 * * *$ & 0.203 \\
\hline$\kappa_{3}$ & -0.644 & 0.379 & -0.077 & $2.532 * * *$ & $1.089 * * *$ \\
\hline$\kappa_{4}$ & 0.281 & $2.115^{* *}$ & $1.581^{* *}$ & $3.478 * * *$ & $2.271 * * *$ \\
\hline Log-likelihood & -1469.38 & -995.77 & -2414.55 & -2700.28 & -7712.38 \\
\hline $\begin{array}{l}\text { Number of } \\
\text { observations }\end{array}$ & 1075 & 748 & 1846 & 2075 & 5744 \\
\hline
\end{tabular}

Notes: The dependent variable is the level of deadweight $(1,2,3,4,5)$ in project $i$. Estimated parameters are reported. Significance levels are based on robust standard errors. Definitions of variables are given in Table $4 . *(* *, * * *)=$ statistically significant at the $0.10(0.05,0.01)$ level. ${ }^{\text {a) }}$ Reference project category is development project; ${ }^{b)}$ reference industry is business services; ${ }^{c}$ reference year is 2003 . 
Table 6. Average marginal effects on deadweight spending ( $€ 1000)$

\begin{tabular}{|c|c|c|c|c|c|}
\hline Variable & $\begin{array}{l}\text { Assisted } \\
\text { Area } 1\end{array}$ & $\begin{array}{l}\text { Assisted } \\
\text { Area } 2\end{array}$ & $\begin{array}{l}\text { Assisted } \\
\text { Area } 3\end{array}$ & $\begin{array}{c}\text { Outside } \\
\text { Assisted } \\
\text { Areas }\end{array}$ & $\begin{array}{c}\text { All } \\
\text { Areas }\end{array}$ \\
\hline \multirow[t]{2}{*}{ New firm } & -1.158 & -0.291 & -0.499 & -0.001 & -0.221 \\
\hline & {$[-6.6 \%]$} & {$[-1.9 \%]$} & {$[-4.5 \%]$} & {$[0.0 \%]$} & {$[-1.9 \%]$} \\
\hline \multirow[t]{2}{*}{ Self-employed } & -1.175 & 2.240 & -0.906 & $-2.544 * * *$ & $-1.481 * * *$ \\
\hline & {$[-6.8 \%]$} & {$[14.5 \%]$} & {$[-8.2 \%]$} & {$[-33.9 \%]$} & {$[-12.7 \%]$} \\
\hline Employees & 0.004 & -0.016 & $-0.018 *$ & 0.010 & 0.001 \\
\hline (10 persons) & {$[0.0 \%]$} & {$[-0.1 \%]$} & {$[-0.2 \%]$} & {$[0.1 \%]$} & {$[0.0 \%]$} \\
\hline Turnover of firm & 0.189 & 0.187 & $0.147 * *$ & -0.019 & 0.082 \\
\hline (€ million) & {$[1.1 \%]$} & {$[1.2 \%]$} & {$[1.3 \%]$} & {$[-0.3 \%]$} & {$[0.7 \%]$} \\
\hline Public subsidy & $-0.699 * *$ & -0.537 & -0.112 & 0.061 & -0.046 \\
\hline$(€ 10000)$ & {$[-4.0 \%]$} & {$[-3.5 \%]$} & {$[-1.0 \%]$} & {$[0.8 \%]$} & {$[-0.4 \%]$} \\
\hline Project costs & $0.171 *$ & 0.097 & -0.002 & -0.013 & -0.009 \\
\hline$(€ 10000)$ & {$[1.0 \%]$} & {$[0.6 \%]$} & {$[0.0 \%]$} & {$[-0.2 \%]$} & {$[-0.1 \%]$} \\
\hline \multirow{2}{*}{$\begin{array}{l}\text { Intensity of assistance } \\
(\%)\end{array}$} & 0.170 & -0.091 & $-0.078^{*}$ & $-0.082 * * *$ & $-0.121 * * *$ \\
\hline & [1.0\%] & {$[-0.6 \%]$} & {$[-0.7 \%]$} & {$[-1.1 \%]$} & {$[-1.0 \%]$} \\
\hline \multirow[t]{2}{*}{ Investment project ${ }^{\mathrm{a}}$} & 3.079 & -0.613 & 0.006 & -1.109 & $-1.331 * *$ \\
\hline & {$[20.9 \%]$} & {$[-3.9 \%]$} & {$[0.1 \%]$} & {$[-14.5 \%]$} & {$[-10.7 \%]$} \\
\hline \multirow[t]{2}{*}{ Start-up project ${ }^{\mathrm{a}}$} & 2.336 & 1.003 & $-1.662 * *$ & 0.449 & -0.071 \\
\hline & {$[15.9 \%]$} & {$[6.3 \%]$} & {$[-15.0 \%]$} & [5.9\%] & {$[-0.6 \%]$} \\
\hline \multirow[t]{2}{*}{ Metal $^{\mathrm{b}}$} & $-2.562 *$ & 0.331 & -0.699 & -0.251 & $-0.746 * *$ \\
\hline & {$[-12.7 \%]$} & {$[2.1 \%]$} & {$[-6.0 \%]$} & {$[-3.4 \%]$} & {$[-6.1 \%]$} \\
\hline \multirow[t]{2}{*}{ Wood $^{\text {b }}$} & $-5.347 * * *$ & -1.723 & -0.922 & -0.276 & $-1.349 * * *$ \\
\hline & {$[-26.7 \%]$} & {$[-10.9 \%]$} & {$[-7.9 \%]$} & {$[-3.7 \%]$} & {$[-11.0 \%]$} \\
\hline \multirow[t]{2}{*}{ Other manufacturing ${ }^{\mathrm{b}}$} & $-2.826^{*}$ & 0.099 & $-1.013 *$ & 0.048 & $-0.734 * *$ \\
\hline & {$[-14.1 \%]$} & {$[0.6 \%]$} & {$[-8.7 \%]$} & {$[0.6 \%]$} & {$[-6.0 \%]$} \\
\hline \multirow[t]{2}{*}{ Trade $^{b}$} & -1.925 & 0.760 & -0.672 & -0.453 & -0.354 \\
\hline & {$[-9.6 \%]$} & [4.8\%] & {$[-5.8 \%]$} & {$[-6.0 \%]$} & {$[-2.9 \%]$} \\
\hline \multirow[t]{2}{*}{ Transport $^{\mathrm{b}}$} & -2.786 & 0.299 & -2.409 & -0.780 & -0.911 \\
\hline & {$[-13.9 \%]$} & {$[1.9 \%]$} & {$[-20.7 \%]$} & {$[-10.4 \%]$} & {$[-7.4 \%]$} \\
\hline \multirow[t]{2}{*}{ Other industries ${ }^{\mathrm{b}}$} & $-3.740 *$ & -1.025 & 0.232 & 0.318 & -0.163 \\
\hline & {$[-18.6 \%]$} & {$[-6.5 \%]$} & {$[2.0 \%]$} & {$[4.2 \%]$} & {$[-1.3 \%]$} \\
\hline \multirow[t]{2}{*}{ Unemployment rate $(\%)$} & -0.138 & $0.250 * *$ & $-0.246 * *$ & $0.167 * * *$ & $0.101 * *$ \\
\hline & {$[-0.8 \%]$} & {$[1.6 \%]$} & {$[-2.2 \%]$} & {$[2.3 \%]$} & {$[0.9 \%]$} \\
\hline Disposable income & -2.101 & -0.549 & -0.057 & $0.544 * * *$ & $0.298 * *$ \\
\hline (€ 1000, per capita) & {$[-12.2 \%]$} & {$[-3.5 \%]$} & {$[-0.5 \%]$} & {$[7.3 \%]$} & {$[2.6 \%]$} \\
\hline R\&D expenditure & -0.224 & -0.735 & $1.408 * *$ & -0.210 & 0.011 \\
\hline (€ 1000 , per capita) & {$[-1.3 \%]$} & {$[-4.7 \%]$} & {$[12.8 \%]$} & {$[-2.8 \%]$} & {$[0.1 \%]$} \\
\hline \multirow[t]{2}{*}{$2000^{c}$} & 1.010 & 0.840 & $1.491 *$ & 0.328 & $1.298 * * *$ \\
\hline & {$[5.5 \%]$} & {$[5.4 \%]$} & {$[14.5 \%]$} & {$[4.8 \%]$} & {$[11.8 \%]$} \\
\hline \multirow[t]{2}{*}{$2001^{\mathrm{c}}$} & -2.532 & -0.517 & 0.195 & $0.804 * *$ & 0.395 \\
\hline & {$[-13.9 \%]$} & {$[-3.3 \%]$} & {$[1.9 \%]$} & {$[11.7 \%]$} & {$[3.6 \%]$} \\
\hline \multirow[t]{2}{*}{$2002^{c}$} & -2.152 & -1.288 & 0.358 & 0.562 & 0.190 \\
\hline & {$[-11.8 \%]$} & {$[-8.3 \%]$} & {$[3.5 \%]$} & {$[8.2 \%]$} & {$[1.7 \%]$} \\
\hline$E\left(y \mid x_{r}\right)$ & 16.804 & 14.724 & 10.645 & 7.457 & 11.170 \\
\hline
\end{tabular}

Notes: Marginal effects have been computed as averages over observations using equation (A1) in the Appendix. Average percentage changes in expected deadweight spending are given in square brackets below. Definitions of variables are given in Table $4 . *(* *, * * *)=$ statistically significant at the 0.10 $(0.05,0.01)$ level. Significance levels are based on 750 bootstrap samples. ${ }^{a)}$ Reference project category is development project; ${ }^{\text {b) }}$ reference industry is business services; ${ }^{\text {c) }}$ reference year is 2003. 
Table 7. Decomposition of pair-wise regional differences in expected deadweight spending $(€)$

\begin{tabular}{lcccccc}
\hline $\begin{array}{l}\text { Two regions } \\
\text { compared }\end{array}$ & $\begin{array}{c}\text { Due to differences } \\
\text { in observed } \\
\text { characteristics }\end{array}$ & \multicolumn{2}{c}{$\begin{array}{c}\text { Unexplained } \\
\text { difference }\end{array}$} & \multicolumn{2}{c}{$\begin{array}{c}\text { Total } \\
\text { difference }\end{array}$} \\
\hline Area 1 \& Area 2 & $€ 952$ & $(45.8 \%)$ & $€ 1128$ & $(54.2 \%)$ & $€ 2080^{\mathrm{a}}$ & $(100 \%)$ \\
Area 1 \& Area 3 & $€ 5744$ & $(93.3 \%)$ & $€ 415$ & $(6.7 \%)$ & $€ 6159$ & $(100 \%)$ \\
Area 1 \& Outside & $€ 9319$ & $(99.7 \%)$ & $€ 29$ & $(0.3 \%)$ & $€ 9347$ & $(100 \%)$ \\
Area 2 \& Area 3 & $€ 3957$ & $(97.0 \%)$ & $€ 122$ & $(3.0 \%)$ & $€ 4079$ & $(100 \%)$ \\
Area 2 \& Outside & $€ 7250$ & $(99.8 \%)$ & $€ 17$ & $(0.2 \%)$ & $€ 7267$ & $(100 \%)$ \\
Area 3 \& Outside & $€ 3073$ & $(96.4 \%)$ & $€ 115$ & $(3.6 \%)$ & $€ 3188$ & $(100 \%)$ \\
\hline Notes: & $\begin{array}{l}\text { Figures have been computed using equation (4) and the parameters reported in Table 5 (averages } \\
\text { over observations). Row percentages are reported in parentheses. Area 1, 2, 3 = Assisted Area 1, }\end{array}$ \\
& 2, 3; Outside = Outside Assisted Areas. ${ }^{\text {a) }}$ Average deadweight spending in Assisted Area 1 - \\
Average deadweight spending in Assisted Area 2, $€$. & & &
\end{tabular}


Table 8. Estimated regional deadweight spending with alternative policy schemes (€ 1000$)$

\begin{tabular}{|c|c|c|c|c|c|}
\hline Policy schemes & $\begin{array}{c}\text { Assisted } \\
\text { Area } 1\end{array}$ & $\begin{array}{c}\text { Assisted } \\
\text { Area } 2\end{array}$ & $\begin{array}{c}\text { Assisted } \\
\text { Area } 3\end{array}$ & $\begin{array}{c}\text { Outside } \\
\text { Assisted } \\
\text { Areas }\end{array}$ & Total \\
\hline \multicolumn{6}{|l|}{ (1) Current policy } \\
\hline Public subsidies & 67959 & 35544 & 57412 & 44002 & 204917 \\
\hline Deadweight spending & 18065 & 11013 & 19651 & 15473 & 64202 \\
\hline \multicolumn{6}{|c|}{ (2a) Redistribute grants from Outside Areas to Assisted Area 1, 2 and 3} \\
\hline Public subsidies & $\begin{array}{c}86542 \\
{[+27.3 \%]}\end{array}$ & $\begin{array}{c}45263 \\
{[+27.3 \%]}\end{array}$ & $\begin{array}{c}73111 \\
{[+27.3 \%]}\end{array}$ & $\begin{array}{c}0 \\
{[-100 \%]}\end{array}$ & $\begin{array}{c}204917 \\
{[0 \%]}\end{array}$ \\
\hline Deadweight spending & $\begin{array}{c}18421 \\
{[+2.0 \%]}\end{array}$ & $\begin{array}{c}11155 \\
{[+1.3 \%]}\end{array}$ & $\begin{array}{c}23053 \\
{[+17.3 \%]}\end{array}$ & $\begin{array}{c}0 \\
{[-100 \%]}\end{array}$ & $\begin{array}{c}52629 \\
{[-18.0 \%]}\end{array}$ \\
\hline \multicolumn{6}{|c|}{ (2b) Redistribute grants from Outside Areas to Assisted Area 1 and 2} \\
\hline Public subsidies & $\begin{array}{c}96850 \\
{[+42.5 \%]}\end{array}$ & $\begin{array}{c}50655 \\
{[+42.5 \%]}\end{array}$ & $\begin{array}{c}57412 \\
{[0 \%]}\end{array}$ & $\begin{array}{c}0 \\
{[-100 \%]}\end{array}$ & $\begin{array}{c}204917 \\
{[0 \%]}\end{array}$ \\
\hline Deadweight spending & $\begin{array}{c}19053 \\
{[+5.5 \%]}\end{array}$ & $\begin{array}{c}10966 \\
{[-0.4 \%]}\end{array}$ & $\begin{array}{c}19651 \\
{[0 \%]}\end{array}$ & $\begin{array}{c}0 \\
{[-100 \%]}\end{array}$ & $\begin{array}{c}49670 \\
{[-22.6 \%]}\end{array}$ \\
\hline \multicolumn{6}{|c|}{ (2c) Redistribute grants from Outside Areas to Assisted Area 1} \\
\hline Public subsidies & $\begin{array}{c}111961 \\
{[+64.7 \%]}\end{array}$ & $\begin{array}{c}35544 \\
{[0 \%]}\end{array}$ & $\begin{array}{c}57412 \\
{[0 \%]}\end{array}$ & $\begin{array}{c}0 \\
{[-100 \%]}\end{array}$ & $\begin{array}{c}204917 \\
{[0 \%]}\end{array}$ \\
\hline Deadweight spending & $\begin{array}{c}20393 \\
{[+12.9 \%]}\end{array}$ & $\begin{array}{c}11013 \\
{[0 \%]}\end{array}$ & $\begin{array}{c}19651 \\
{[0 \%]}\end{array}$ & $\begin{array}{c}0 \\
{[-100 \%]}\end{array}$ & $\begin{array}{c}51058 \\
{[-20.5 \%]}\end{array}$ \\
\hline \multicolumn{6}{|c|}{ (3a) Reduce the amount of grants by $50 \%$ and distribute them all to Assisted Area $1 \& 2$} \\
\hline Public subsidies & $\begin{array}{c}67273 \\
{[-1.0 \%]}\end{array}$ & $\begin{array}{l}35185 \\
{[-1.0 \%]}\end{array}$ & $\begin{array}{c}0 \\
{[-100 \%]}\end{array}$ & $\begin{array}{c}0 \\
{[-100 \%]}\end{array}$ & $\begin{array}{c}102458 \\
{[-50.0 \%]}\end{array}$ \\
\hline Deadweight spending & $\begin{array}{c}18094 \\
{[+0.2 \%]}\end{array}$ & $\begin{array}{c}10993 \\
{[-0.2 \%]}\end{array}$ & $\begin{array}{c}0 \\
{[-100 \%]}\end{array}$ & $\begin{array}{c}0 \\
{[-100 \%]}\end{array}$ & $\begin{array}{c}29086 \\
{[-54.7 \%]}\end{array}$ \\
\hline \multicolumn{6}{|c|}{ (3b) Reduce the amount of grants by 50\% and distribute them all to Assisted Area 1} \\
\hline Public subsidies & $\begin{array}{c}102458 \\
{[+50.8 \%]}\end{array}$ & $\begin{array}{c}0 \\
{[-100 \%]}\end{array}$ & $\begin{array}{c}0 \\
{[-100 \%]}\end{array}$ & $\begin{array}{c}0 \\
{[-100 \%]}\end{array}$ & $\begin{array}{c}102458 \\
{[-50.0 \%]}\end{array}$ \\
\hline Deadweight spending & $\begin{array}{c}19496 \\
{[+7.9 \%]}\end{array}$ & $\begin{array}{c}0 \\
{[-100 \%]}\end{array}$ & $\begin{array}{c}0 \\
{[-100 \%]}\end{array}$ & $\begin{array}{c}0 \\
{[-100 \%]}\end{array}$ & $\begin{array}{c}19496 \\
{[-69.6 \%]}\end{array}$ \\
\hline Number of observations & 1075 & 748 & 1846 & 2075 & 5744 \\
\hline Notes: Regional aggregates & given. I1 & are based on & e project-1 & imulation & $\begin{array}{l}\text { ng equation } \\
\text { elow. In the }\end{array}$ \\
\hline
\end{tabular}


Table A1. Mean values of variables by region

\begin{tabular}{|c|c|c|c|c|c|}
\hline Variable & $\begin{array}{c}\text { Assisted } \\
\text { Area } 1\end{array}$ & $\begin{array}{c}\text { Assisted } \\
\text { Area } 2\end{array}$ & $\begin{array}{c}\text { Assisted } \\
\text { Area } 3\end{array}$ & $\begin{array}{c}\text { Outside } \\
\text { Assisted } \\
\text { Areas }\end{array}$ & $\begin{array}{c}\text { All } \\
\text { Areas }\end{array}$ \\
\hline \multicolumn{6}{|l|}{ Firm characteristics } \\
\hline New firm & 0.247 & 0.241 & 0.218 & 0.252 & 0.239 \\
\hline Self-employed & 0.041 & 0.064 & 0.074 & 0.041 & 0.054 \\
\hline Employees (persons) ${ }^{\mathrm{a}}$ & 16.893 & 13.304 & 17.099 & 15.818 & 16.103 \\
\hline Turnover of firm (€ millions $)^{\mathrm{a}}$ & 1.681 & 1.423 & 1.996 & 1.729 & 1.766 \\
\hline \multicolumn{6}{|l|}{ Project characteristics } \\
\hline Public subsidy ( $€ 1000$ ) & 63.218 & 47.519 & 31.101 & 21.206 & 35.675 \\
\hline Project costs $(€ 1000)$ & 209.585 & 177.363 & 193.844 & 91.761 & 157.767 \\
\hline Intensity of assistance & 35.895 & 32.057 & 27.087 & 34.899 & 32.205 \\
\hline \multicolumn{6}{|l|}{ Type of project } \\
\hline Investment project & 0.647 & 0.715 & 0.621 & 0.315 & 0.528 \\
\hline Start-up project & 0.265 & 0.242 & 0.295 & 0.510 & 0.360 \\
\hline Development project (ref.) & 0.087 & 0.043 & 0.083 & 0.175 & 0.112 \\
\hline \multicolumn{6}{|l|}{ Industry } \\
\hline Metal & 0.252 & 0.154 & 0.317 & 0.219 & 0.248 \\
\hline Wood & 0.143 & 0.205 & 0.150 & 0.087 & 0.133 \\
\hline Other manufacturing & 0.249 & 0.194 & 0.243 & 0.293 & 0.256 \\
\hline Trade & 0.041 & 0.134 & 0.044 & 0.053 & 0.058 \\
\hline Transport & 0.020 & 0.059 & 0.007 & 0.014 & 0.019 \\
\hline Business services (ref.) & 0.221 & 0.143 & 0.170 & 0.263 & 0.210 \\
\hline Other industries & 0.073 & 0.112 & 0.069 & 0.071 & 0.076 \\
\hline \multicolumn{6}{|l|}{ Regional characteristics } \\
\hline Unemployment rate & 17.840 & 18.127 & 14.969 & 11.164 & 14.543 \\
\hline Disposable income & 11.598 & 11.038 & 12.121 & 13.536 & 12.393 \\
\hline R\&D expenditure & 0.295 & 0.183 & 0.349 & 1.119 & 0.595 \\
\hline \multicolumn{6}{|l|}{ Year } \\
\hline 2000 & 0.371 & 0.405 & 0.356 & 0.312 & 0.349 \\
\hline 2001 & 0.337 & 0.324 & 0.306 & 0.348 & 0.329 \\
\hline 2002 & 0.207 & 0.190 & 0.230 & 0.228 & 0.220 \\
\hline 2003 (ref.) & 0.085 & 0.082 & 0.108 & 0.112 & 0.102 \\
\hline Number of observations & 1075 & 748 & 1846 & 2075 & 5744 \\
\hline
\end{tabular}


Table A2. Robustness checks of the pair-wise differences due to differences in observed characteristics (\%)

\begin{tabular}{lcrrrrr}
\hline \multirow{2}{*}{ Two regions compared } & \multicolumn{6}{c}{ Alternative specifications } \\
\cline { 2 - 7 } & A.1 & A.2 & \multicolumn{1}{c}{ A.3 } & \multicolumn{1}{c}{ B.1 } & \multicolumn{1}{c}{ B.2 } & \multicolumn{1}{c}{ B.3 } \\
\hline Area 1 \& Area 2 & $45.8 \%$ & $58.4 \%$ & $61.3 \%$ & $40.8 \%$ & $52.6 \%$ & $52.9 \%$ \\
Area 1 \& Area 3 & $93.3 \%$ & $99.9 \%$ & $100.9 \%$ & $98.1 \%$ & $102.3 \%$ & $102.8 \%$ \\
Area 1 \& Outside & $99.7 \%$ & $111.6 \%$ & $106.8 \%$ & $102.6 \%$ & $111.9 \%$ & $107.6 \%$ \\
Area 2 \& Area 3 & $97.0 \%$ & $109.2 \%$ & $102.6 \%$ & $88.3 \%$ & $103.1 \%$ & $95.4 \%$ \\
Area 2 \& Outside & $99.8 \%$ & $116.6 \%$ & $105.3 \%$ & $99.5 \%$ & $115.4 \%$ & $105.2 \%$ \\
Area 3 \& Outside & $96.4 \%$ & $116.3 \%$ & $101.1 \%$ & $98.2 \%$ & $115.8 \%$ & $102.4 \%$ \\
\hline Imputed missing values $^{\text {a }}$ & yes & yes & yes & no & no & no \\
\hline Notes: & 1-3 indicate alternative assumptions about the computation of deadweight spending: 1) reduced \\
\multicolumn{2}{l}{ scale implies 25\%, reduced qualitative level implies 50\% and later date implies $75 \%$ of } \\
deadweight; 2) they all imply 50\% of deadweight; 3) they imply 50, 70, and 90\% of deadweight, \\
respectively. ${ }^{\text {a) }}$ Missing values are imputed for a firm's turnover and number of employees.
\end{tabular}




\section{Notes}

${ }^{1}$ Besides project additionality, output additionality, input additionality, behavioural additionality and cognitive capacity additionality are also recognized in the subsidy literature (see DAVENPORT et al., 1998; GEORGHIOU et al., 2002).

${ }^{2}$ Displacement occurs if a subsidized project reduces activity elsewhere in the economy (TERVO, 1989, 1990).

${ }^{3}$ Deadweight spending may also occur in the case of repayable grants, i.e., loans and guarantees. However, in monetary terms, the public sector loss is not that critical if the subsidy is refunded with interest to the public sector.

${ }^{4}$ A micro-sized (small-sized, medium-sized) enterprise is an enterprise that employs fewer than $10(50,250)$ persons, has an annual turnover not exceeding $€ 2(10,50)$ million or an annual balance sheet total not exceeding $€ 2(10,43)$ million, and fulfils the characteristics depicting the autonomy of an enterprise (EUROPEAN COMMISSION, 2003).

${ }^{5}$ The Ministry of Trade and Industry only makes financing decisions in cases in which the cost of an investment project exceeds $€ 1.7$ million.

${ }^{6}$ Although strong economic growth temporarily slowed down in Finland in 2000-2003, the profitability of enterprises remained positive and largely unchanged (see STATISTICS FINLAND, 2004; OECD, 2009).

${ }^{7}$ One hundred public sector projects were excluded from the analysis.

8 Possible bias problems in deadweight measures are discussed in TOKILA and HAAPANEN (2009).

9 We have missing values for turnover or the number of employees for 812 observations. These missing values were imputed using predicted values from two regression models in which turnover and the number of employees were regressed on the remaining variables in the data. 
${ }^{10}$ The LR test compares the sum of the log-likelihoods of the regional models with the $\log$-likelihood for the entire country. The $\chi^{2}(75)$ distributed test statistic was $264.8(p<$ 0.001). We also estimated parameters in column 5 together with three regional dummies, but the specification was rejected in favour of columns $1-4(p<0.001)$.

${ }^{11}$ Our additional analyses show that elasticity of deadweight spending is close to one in Assisted Area 1. That is, a 1\% increase in the public subsidies is on average associated with a $1.03 \%$ increase in deadweight spending. In all other regions, elasticity is between $0.60 \%$ and $0.76 \%$.

${ }^{12}$ We also used the NUTS4 population as an additional explanatory variable. However, because it was not significant in any of the regional models and did not alter the results, we decided to drop it from the final specification.

${ }^{13}$ For further details on the estimation of treatment effects and other recent advances in econometric methods, see ANGRIST and PISCHKE (2009). Problems related to sample selection are also discussed in GREENE (2008, Ch. 24.5). Regarding other methodological approaches available for the evaluation of deadweight, including the cost-benefit analysis (e.g. WREN 2007), see the discussion and references in LENIHAN and HART $(2004,2006)$. The net impacts of subsidies are recently investigated with treatment models by KANGASHARJU (2007) and MOLE et al. (2008). 